\title{
Analysis of stemness gene expression and CD133 abnormal methylation in neuroblastoma cell lines
}

\author{
PAULA SCHIAPPARELLI ${ }^{1}$, MÓNICA ENGUITA-GERMÁN ${ }^{1}$, JANA BALBUENA ${ }^{1}$, \\ JUAN A. REY ${ }^{2}$, PAULA LÁZCOZ ${ }^{3}$ and JAVIER S. CASTRESANA ${ }^{1}$ \\ ${ }^{1}$ Brain Tumor Biology Unit-CIFA, University of Navarra School of Sciences, Pamplona; ${ }^{2}$ Research Unit, \\ La Paz University Hospital, Madrid; ${ }^{3}$ Department of Health Sciences, Public University of Navarra, Pamplona, Spain
}

Received June 29, 2010; Accepted August 2, 2010

DOI: $10.3892 /$ or_00000993

\begin{abstract}
Neuroblastoma is the most common extracranial solid tumor in children, accounting for up to $10 \%$ of all childhood malignancies. Cellular heterogeneity is a hallmark of this embryonal cancer, as distinct neural crest lineages can be found within the same tumor sample. The aim of our study was to investigate the presence of a subpopulation of immature cells with features of cancer-like stem cells in 10 neuroblastoma cell lines. RT-PCR and flow cytometry were performed in order to analyze different kinds of 'stemness genes’ such as: NESTIN (NES), CD133, SOX-2, BMI1, c-KIT, MELK1, MUSASHI-1 (MSI1), FAS, CD44 and VIMENTIN (VIM). In addition, glial and neuronal markers such as NCAM1, GFAP and B-TUBULIN III (TUBB3) were analyzed. Epigenetic changes within the CD133 (Prominin-1) gene promoter were also analyzed. Neuroblastoma cell lines showed a particular pattern of expression, suggesting the presence of an immature cancer stem cell-like subpopulation. The CD133 protein, commonly used to enrich putative cancer propagating stem cell-like populations in different kinds of solid tumors, presented a half-methylated DNA state in 7 of the 12 neuroblastoma cell lines analyzed. An increase in RNA and protein levels of CD133 was achieved following demethylation by assays using 5-aza-2'-deoxycytidine (5-Aza-dC). Since cancer stem cells are believed to be responsible for tumor metastasis, escape from anticancer therapies and disease relapse, their therapeutic targeting and analysis is crucial in neuroblastoma. Moreover, the regulation of CD133 by epigenetic changes may provide an innovative mechanism of CD133 expression as its regulation still remains unclear.
\end{abstract}

Correspondence to: Dr Javier S. Castresana, Unidad de Biología de Tumores Cerebrales, CIFA, Universidad de Navarra, Irunlarrea 1, 31008 Pamplona, Spain

E-mail: jscastresana@unav.es

Key words: neuroblastoma, CD133, epigenetics, neural stem cells

\section{Introduction}

Neuroblastoma, the most common extracranial solid tumor of childhood, is believed to be caused by the primordial neural crest derived cells that give rise to tumors of the sympathetic nervous system and the adrenal gland (1). Evidence suggests that malignancies can arise or be maintained by neural stem cells (NSC) with the attributes of limitless replication and self-renewal that can undergo a transformation to brain tumor stem cells (BTSC) (2). The Notch, Sonic hedgehog, and Wnt/ß-catenin developmental programs play a crucial part in stem cell determination and renewal in diverse tissues. Pathway dysregulation can be an important feature in embryonal tumors such as neuroblastoma or medulloblastoma (3-5). The study of tumor stem cells in neuroblastoma could be informative for the understanding of the biological heterogeneity of this tumor that can behave in unpredictable ways, from showing spontaneous regression to relentless progression (6-8).

The expression of marker genes and proteins related to BTSC and immature cells can give important information on the presence of a population of this type of cells in neuroblastoma tumors or cell lines. CD133 (also named Prominin-1) is a cell surface glycoprotein with 5 transmembrane domains and two glycosylated extracellular loops with a molecular weight of 97-120 kDa $(9,10)$. CD133 was originally described as a hematopoietic stem cell marker. It is expressed by immature hematopoietic stem cells and is a marker for other stem and progenitor cells including neural and embryonic stem cells (11). It has been shown to be expressed in several tumor tissues, including some hematologic neoplasias such as leukemias and a number of solid tumors such as brain, colon, ovarian and prostate neoplasias (12-15). At least five alternative promoters with five alternative first exons have been found for this gene. Different spliced transcripts have been described and there appears to be a tissue-dependent relationship with respect to the spliced isoforms (16). However, the mechanisms for CD133 regulation of expression remain unclear.

Epigenetic events lead to variations in gene expression. DNA methylation patterns become important hallmarks of tumor development and progression $(17,18)$. Interestingly, epigenetic changes on a promoter region of CD133 region 
have been described on glioblastoma, ovarian and colorectal tumors (19-21). Although CD133 function on cell biology its not clear, methylation status of this stem cell marker may be an important feature for understanding the behaviour of cancer stem cells in tumor biology.

The aim of our study was to investigate the presence of a subpopulation of immature cells with features of cancer-like stem cells on neuroblastoma cell lines. For this propose, we chose different types of interesting immature marker genes such as: NESTIN (NES), CD133, Sox-2, BMI1, c-KIT, MELK1, MUSHASHI-1 (MSI1), FAS, CD44, and VIMENTIN (VIM). The afore-mentioned proteins are those commonly used for the analysis of a subpopulation of cancer stem cells, but have not been fully investigated in neuroblastoma, although some studies are showing increasing evidence of their presence in this embryonal tumor $(8,22,23)$. In addition, other gene markers of mature cells such as NCAM1, GFAP and B-TUBILIN III (TUBB3) were analyzed by RT-PCR and flow cytometry. Epigenetic changes at CD133 were studied as well as expression changes on RNA and protein level after demethylation assays with 5-aza-2'-deoxycytidine (5-Aza-dC).

\section{Materials and methods}

Cell lines. Ten neuroblastoma cell lines were used in this study: SKNDZ, SKNSH, SKNBe(2), SKNF1, and BE(2)C were purchased from the American Type Culture Collection (ATCC, Manassas, VA), and IMR-32, Kelly, SIMA, SHSY5Y, and MHHNB-11 were purchased from the Deutsche Sammlung von Mikroorganismen und Zellkuturen $\mathrm{GmbH}$ (DSMZ, Braunchsweig, Germany). All cell lines were cultured in DMEM+L-Glutamax medium, supplemented with $10 \%$ fetal bovine serum (FBS), 5\% nonessential aminoacids (NEAA), $1 \%$ penicillin/streptomycin and $0.1 \%$ amphotericin $\mathrm{B}$ at $37^{\circ} \mathrm{C}$ with $5 \% \mathrm{CO}_{2}$.

RNA isolation. RNA from the cell lines was purified using the QuickPrep Total RNA extraction kit (Amersham Biosciences Corporation, Piscataway, NJ, USA), following manufacturer's instructions. RNA concentration was measured in a SmartSpec ${ }^{\mathrm{TM}}$ Spectrophotometer (Bio-Rad, Hercules, CA, USA) measuring absorbance at $260 \mathrm{~nm}$.

cDNA synthesis and RT-PCR. Total RNA $(1 \mu \mathrm{g})$ was reversetranscribed using the SuperScript ${ }^{\mathrm{TM}}$ II RNase H Reverse Transcriptase (Invitrogen, Carlsbad, CA, USA), following the manufacturer's instructions. RT-PCR for VIM, B-TUBB3, CD44, CD133, GFAP, NES, NCAM1, MELK1, BMI1, C-KIT, MSI1, FAS, SOX2, MYCN were performed on a Biometra ${ }^{\circledR}$ thermocycler (T3) (Biometra, Göttingen, Germany). Approximately $100 \mathrm{ng}$ of cDNA was amplified in a final volume of $25 \mu 1$. The reaction mix contained $2.5 \mu 110 \mathrm{X}$ reaction buffer, 1.5-2.5 mM $\mathrm{MgCl}_{2}, 0.2 \mathrm{mM}$ of each dNTP, 5-10 pmol of forward and reverse primers, 5\% DMSO and one unit of AmpliTaq Gold ${ }^{\mathrm{TM}}$ polymerase (Applied Biosystems, Foster City, CA, USA). A denaturation step at $95^{\circ} \mathrm{C}$ for 10 min was followed by 30-40 cycles of amplification, alternating between $95^{\circ} \mathrm{C}$ for $1 \mathrm{~min}$, the corresponding annealing temperature for each gene for $45 \mathrm{sec}$ to $1 \mathrm{~min}$, and $72^{\circ} \mathrm{C}$ for $45 \mathrm{sec}$ to $2 \mathrm{~min}$. A final extension step at $72^{\circ} \mathrm{C}$ for 10 min was added. The housekeeping gene for the transferring receptor (TFR, 3q29) was used as an internal control of expression in all reactions. PCR products were visualized in $2 \%$ agarose gels stained with ethidium bromide at a final concentration of $0.1 \mu \mathrm{g} / \mathrm{ml}$. Primer sequences are detailed in Table I. All primers were designed using Primer 3 software.

Analysis of protein expression by flow cytometry. Protein expression of CD133, NES, MSI1, FAS, NCAM1, GFAP and B-TUBB3 was performed by flow cytometry. One million cells were incubated with CD133/1 (Miltenyi Biotec, 1:11), FAS (Serotec, 1:100) and NCAM1 (Chemicon, 1:100) for 10-30 min at $4^{\circ} \mathrm{C}$. For FAS and NCAM1 detection, secondary antibodies Cy2-donkey anti-mouse IgG (Jackson Immunoresearch) and FITC-donkey anti-rabbit IgG (Jackson Immunoresearch) were added, diluted 1:100 respectively and incubated for $30 \mathrm{~min}$ at $4^{\circ} \mathrm{C}$. For NESTIN (Chemicon, 1:100), MUSASHI-1 (Chemicon, 1:50), GFAP (Chemicon, 1:1000) and B-TUBULIN III (Chemicon 1:100), we used the Fixation/ Permeabilization solution kit (BD Biosciences). Finally, cells were analyzed in a Beckman Coulter EPIS XL cytometer. The experiments were performed in triplicate.

DNA extraction. DNA from the cell lines was purified using the Wizard ${ }^{\circledR}$ Genomic DNA purification kit (Promega Corporation, Madison, WI, USA) according to the manufacturer's instructions.

DNA bisulfite treatment. Bisulfite modification of purified genomic DNA was performed using the CpGenome ${ }^{\mathrm{TM}}$ DNA modification kit (Chemicon ${ }^{\circledR}$ International Inc., Temecula, CA, USA). Modified DNA was purified, eluted in $1 \mathrm{mM}$ TE ( $\mathrm{pH} 8.0$ ), and used immediately or stored at $-80^{\circ} \mathrm{C}$ for up to six months. Normal genomic blood DNA and in vitro hypermethylated genomic DNA (Genome ${ }^{\mathrm{TM}}$ Universal Methylated DNA, Chemicon International Inc.) were used as negative and positive controls, respectively, for the methylation status of DNA.

Methylation specific PCR (MSP). The promoter region of CD133 was analyzed by MSP. The reaction was carried out in a IQ5 Multicolor real-time PCR detection system (Bio-Rad) using $40 \mathrm{ng}$ of bisulfite modified DNA in a total volume of $25 \mu \mathrm{l}$. The reaction mix contained $2.5 \mu 110 \mathrm{X}$ reaction buffer, 3-4 mM $\mathrm{MgCl}_{2}, 0.2 \mathrm{mM}$ of each dNTP, 5-10 pmol forward and reverse primers, 5\% DMSO and one unit of AmpliTaq Gold polymerase (Applied Biosystems). Denaturation at $95^{\circ} \mathrm{C}$ for $10 \mathrm{~min}$ initiated the reaction, followed by 38 cycles of amplification. A final extension at $72^{\circ} \mathrm{C}$ for $10 \mathrm{~min}$ completed the reaction. PCR products were visualized with ethidium bromide stained $2 \%$ agarose gels. The MSP primers used are described elsewhere (21).

Melting curve analysis-based real-time methylation assay (MCA-Meth). NCAM, TUBB3, VIMENTIN, NESTIN and CD44 were analyzed by MCA-Meth using 3-6 ng of bisulfite modified DNA in a final volume of $25 \mu 1$. The reaction contained $12.5 \mu \mathrm{l}$ of $2 \mathrm{X} \mathrm{IQ}^{\mathrm{TM}} \mathrm{SYBR}$ Green Supermix (Bio$\mathrm{Rad}$ ) and $2.5 \mathrm{pmol}$ of each primer. Primers were designed using MethPrimer software. Primer sequences are detailed in 
Table I. Primer sequences for RT-PCR, MSP, MCA-Meth and qRT-PCR. ${ }^{a}$

\begin{tabular}{|c|c|c|c|}
\hline Name & Forward $\left(5^{\prime}-3^{\prime}\right)$ & Reverse (5'-3') & ${ }^{\circ} \mathrm{C}$ \\
\hline \multicolumn{4}{|l|}{ RT-PCR } \\
\hline VIMENTIN & ACATTGAGATTGCCACCTACAG & ACCGTCTTAATCAGAAGTGTCC & 60 \\
\hline$C D 44$ & GGATTTTAGTTTTTGTTAGGTT & CACСАAААСТТАТССАТААТАТС & 58 \\
\hline$C D 133$ & GCTGATGTTGAAACTGCTTGAG & TGGTGCCGTTGCCTTGG & 64 \\
\hline$C-K I T$ & GCAGAAGCCACCAACACC & GAGAGGACAGCGGACCAG & 62 \\
\hline$G F A P$ & ACGCAGTATGAGGCAATGG & CGGTAGTCGTTGGCTTCG & 56 \\
\hline NESTIN & GTGGCTCCAAGACTTCC & GCACAGGTGTCTCAAGG & 64 \\
\hline$N C A M$ & GAATGCCACCGCCAACC & CAGCCTCGTCGTTCTTATCC & 64 \\
\hline$M E L K-1$ & CACCTCACGGCTACCTATCTTC & TCACTTGCGGTCACATCTTCC & 64 \\
\hline BMI-1 & ATTGTTCGTTACCTGGAGACC & GGCAGCATCAGCAGAAGG & 60 \\
\hline MUSASHII & CCCTGGCTACACCTACC & AGGCAGTGAGAGGAATGG & 60 \\
\hline$F A S$ & GCCAATTCTGCCATAAGC & TTGTCTGTGTACTCCTTCC & 51 \\
\hline SOX 2 & GGCAGCTACAGCATGATGCAGGAC & CTGGGTCATGGAGTACTGCAGG & 65 \\
\hline$T F R$ & GTCAATGTCCCAAACGTCACCAGA & ATTTCGGGAATGCTGAGAAAACAGACAGA & 60 \\
\hline$H P R T$ & TGACACTGGCAAAACAATGCA & GGTCCTTTTCACCAGCAAGCT & 64 \\
\hline \multicolumn{4}{|l|}{ MCA-Meth } \\
\hline VIMENTIN & TGAGGGATTTTTTATTTTTTTT & TCТАААСТАААСТСАСССТААА & 60 \\
\hline$T U B B 3$ & GTTTATGGTAGTTTTTTGGTGGAG & ATCССААСТСССТАТСТTТTААСА & 62 \\
\hline$C D 44$ & GGTTGAATTTAATGGTGTAAG & TTTAAAAAАТАACAАСССТССС & 64 \\
\hline NCAM & GAAGGATATAGTGAGGTTTTTA & TTTTACAAAATTATTTCСТАCC & 58 \\
\hline NESTIN & GTATTTTGGGGAAGTAGGAATAGAG & TCTAАCССАСТАAАAАТАAАСАAАC & 59 \\
\hline \multicolumn{4}{|l|}{ MSP } \\
\hline$C D 133 M$ & GGCGGTTTTATATTTAGGTTTTCGTTC & CGAACCCTCGAACGTAACG & 63 \\
\hline$C D 133 U$ & TTATTATGGTGGTTTTATATTTAGGTTTTTGTTTG & ACTACAACCAAACCСТCAAACATAACA & 63 \\
\hline
\end{tabular}

Table I. The reactions were heated at $95^{\circ} \mathrm{C}$ in a first PCR step for $10 \mathrm{~min}$ and then amplified for 45 cycles of $30 \mathrm{sec}$ at $95^{\circ} \mathrm{C}$, $30 \mathrm{sec}$ at the corresponding annealing temperature and $30 \mathrm{sec}$ at $72^{\circ} \mathrm{C}$. After the amplification step, the melting curve analysis was carried out as follows: from $70^{\circ} \mathrm{C}$ to $90^{\circ} \mathrm{C}, 30 \mathrm{sec}$ at every $0.5^{\circ} \mathrm{C}$. Both the amplification step and the melting curve were carried out in an IQ5 Multicolor real-time PCR detection system (Bio-Rad).

5-aza-dC treatment. All cell lines were treated with $5 \mu \mathrm{M} 5$ Aza-dC for $96 \mathrm{~h}$. Approximately $4 \times 10^{5}$ to $6 \times 10^{5}$ cells were grown in $25 \mathrm{~cm}^{2}$ flasks. During treatment the media was changed daily. Real-time PCR was performed to check for treatment-induced re-expression of CD133.

Real-time PCR. The expression of CD133 was assessed by quantitative real-time PCR. The housekeeping gene for the hypoxanthine phosphoribosyltransferase 1 (HPRT1) was used as an internal control of expression in the reactions. Primer sequences are detailed in Table I. The PCR reactions were carried out in an IQ5 Multicolor real-time PCR detection system (Bio-Rad). The reaction mix contained 12.5 $\mu 12 \mathrm{X} \mathrm{IQ}{ }^{\mathrm{TM}}$ SYBR Green supermix (Bio-Rad) and $12.5 \mathrm{pmol}$ of forward and reverse primers. An initial denaturation step at $95^{\circ} \mathrm{C}$ for 10 min was followed by 30-35 cycles of amplification alternating between $94^{\circ} \mathrm{C}$ for $30 \mathrm{sec}$, $64^{\circ}$ annealing temperature for $30 \mathrm{sec}$, and $72^{\circ} \mathrm{C}$ for $30 \mathrm{sec}$. After the amplification step, the melting curve analysis was carried out as follows: from $70^{\circ} \mathrm{C}$ to $90^{\circ} \mathrm{C}, 30 \mathrm{sec}$ at every $0.5^{\circ} \mathrm{C}$. For the relative quantification, an efficiency corrected quantification model was applied. The derivative ratio values describe the relative expression change of the target gene relative to the HPRT1 reference gene expression.

\section{Results}

RT-PCR expression of immature and differentiation markers. We have determined RNA expression levels of several immature and differentiation markers in 10 neuroblastoma cell lines (Table II). Regarding the immature markers such as CD133, NES and SOX2, generally used as stem cell markers, we observed positive expression in most cell lines analyzed. CD133 marker displayed a variable expression pattern; there were several cell lines showing low expression [IMR-32, SKNBE(2), SKNSH] or no expression (MHHNB11, SKNF1). For BMI1, MSI1, CD44, MELK1, and VIM, all cell lines also showed a widespread positive expression; these immature markers are involved in several regulatory mechanisms shared by NSC and BTSC. On the other hand, c-KIT was not expressed in four cell lines [SKNF1, SHSYSY, KELLY, $\mathrm{BE}(2) \mathrm{C}]$ and presented low expression in two other cell lines (MHHNB11, SKNSH). With regard to the differentiation 
Table II. Expression analysis of immature and differentation markers by RT-PCR in neuroblastoma cell lines.

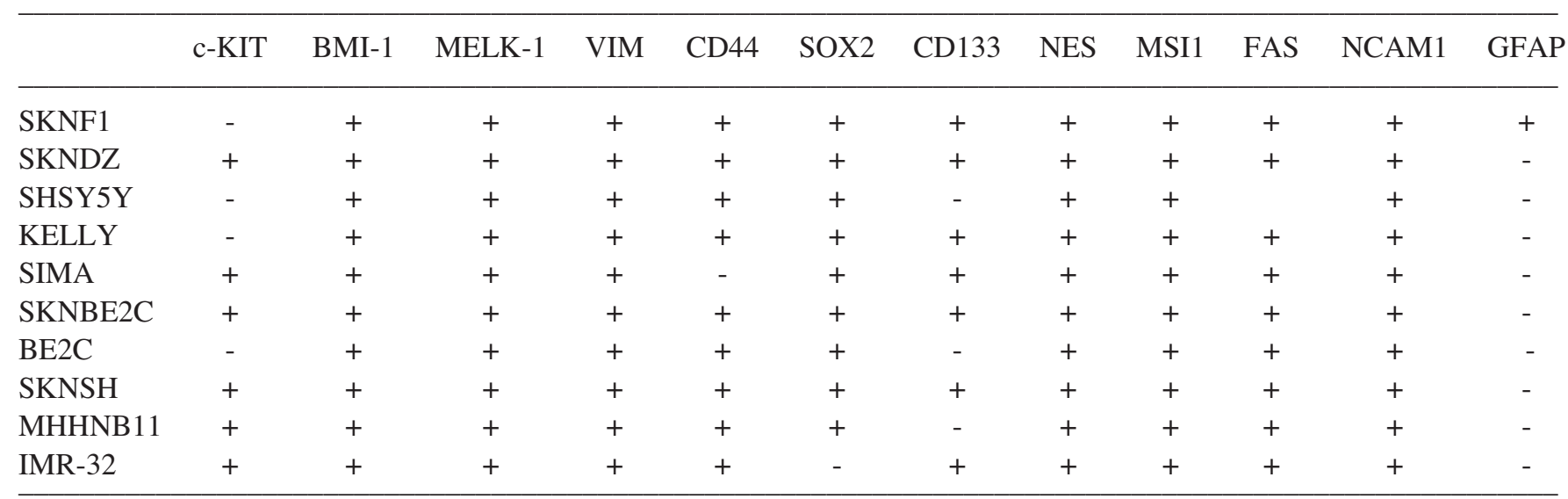

+ , Expression; -, No expression.

Table III. Analysis of protein level of CD133, NES, MSI-1, FAS, NCAM1, GFAP, and TUBB3 by flow cytometry in neuroblastoma cell lines. ${ }^{\mathrm{a}}$

\begin{tabular}{|c|c|c|c|c|c|c|c|}
\hline & \multicolumn{4}{|c|}{ Immature markers } & \multicolumn{3}{|c|}{ Differentiation markers } \\
\hline & CD133 & NES & MSI1 & FAS & NCAM1 & GFAP & ß-Tub III \\
\hline SKNF1 & 0 & 39.4 & 3 & 0 & 20.9 & 0 & 47.1 \\
\hline SKNDZ & 28.3 & 53.4 & 87.8 & 0 & 53.5 & 0 & 75.5 \\
\hline SHSY5Y & 2.7 & 63.2 & 11 & 5 & 7.9 & 0 & 24 \\
\hline KELLY & 1.1 & 31.7 & 1.4 & 0 & 21.5 & 0 & 82.3 \\
\hline SIMA & 33 & 62.8 & 84 & 4.2 & 57.3 & 0 & 81.3 \\
\hline SKNBE2 & 0.5 & 88 & 5.1 & 0 & 9.3 & 0 & 90 \\
\hline $\mathrm{BE} 2 \mathrm{C}$ & 0 & 17.5 & 7.3 & 0 & 13.9 & 0 & 46.1 \\
\hline SKNSH & 8.2 & 92.3 & 0 & 4.7 & 3.7 & 0 & 83 \\
\hline MHHNB11 & 2.6 & 49.4 & 1 & 0 & 29.4 & 0 & 53.8 \\
\hline IMR-32 & 1.4 & 27 & 3 & 0 & 29 & 0 & 27 \\
\hline
\end{tabular}

aData are expressed as percentage of cells expressing a particular marker.

markers, the cell lines were positive for the neuronal marker NCAM1, and negative for the glial marker GFAP.

Protein expression of immature and differentiation markers. The percentage of cells expressing CD133, NES, MSI1, NCAM1, GFAP and TUBB3 proteins in neuroblastoma cell lines was analyzed by flow cytometry. We detected percentages from 0 to $92 \%$, depending on the cell line and marker analyzed (Table III; Fig. 4). RT-PCR results correlated well with protein expression, except for FAS in which the number of positive cells was much lower than expected for the rest of cell lines. The CD133 marker showed the most variable expression pattern: low expression in three cell lines $[\operatorname{SKNBE}(2)$, SKNSH, IMR-32], very high expression in two other cell lines (SKNDZ, SIMA) and no expression in $\mathrm{BE}(2) \mathrm{C}$ and SKNF1. We found very high percentage of CD133 and NES positive cells in several cell lines, but these markers did not appear to be clearly coexpressed, although the two CD133 high expressing cell lines SKNDZ and SIMA presented a correlation of both markers. On the other hand, regarding MSI1, we did find positive correlation with CD133 expression. All cell lines displayed a clear neuronal differentiation lineage, showing expression of neuronal markers, NCAM1 and TUBB3, and no expression of glial marker GFAP.

Promoter methylation of NCAM, VIMENTIN, NESTIN and CD44 by MCA-Meth. Promoter methylation status of immature gene markers NES, CD44 and VIM, and differentiation gene marker NCAM1 was assessed by MCA-Meth or MSP in the neuroblatoma cell lines. We did not find promoter methylation of these markers.

Promoter methylation of CD133 by MSP. We analyzed the promoter methylation status of a $\mathrm{CpG}$ island located between the upstream alternative 5' UTR and exon 2 in 10 neuroblastoma cell lines (21) (Fig. 1). The CD133 promoter was found to be unmethylated in 5 neuroblastoma cell lines: SIMA, 
A

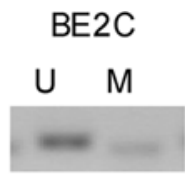

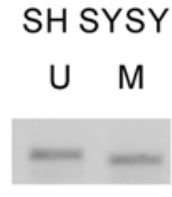

B

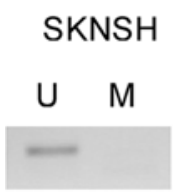

SKNDZ
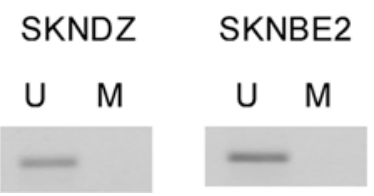

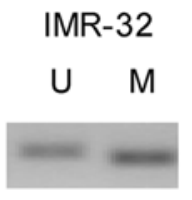

SIMA

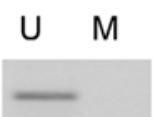

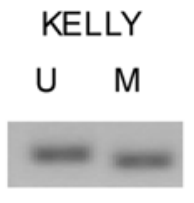

SKNF1
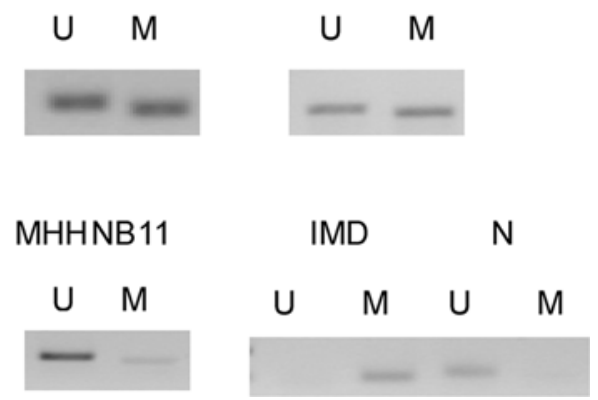

Figure 1. Methylation status of CD133 promoter in neuroblatoma cell lines by MSP. (A) Half methylated cell lines. (B) Unmethylated cell lines. PCR products for the unmethylated $(\mathrm{U})$ and methylated $(\mathrm{M})$ reaction were run on $2 \%$ agarose gels stained with ethidium bromide (0.1 $\mu \mathrm{g} / \mathrm{ml})$. IMD (in vitro methylated DNA): positive control for M reaction; $\mathrm{N}$ (normal genomic DNA): positive control for $\mathrm{U}$ reaction.

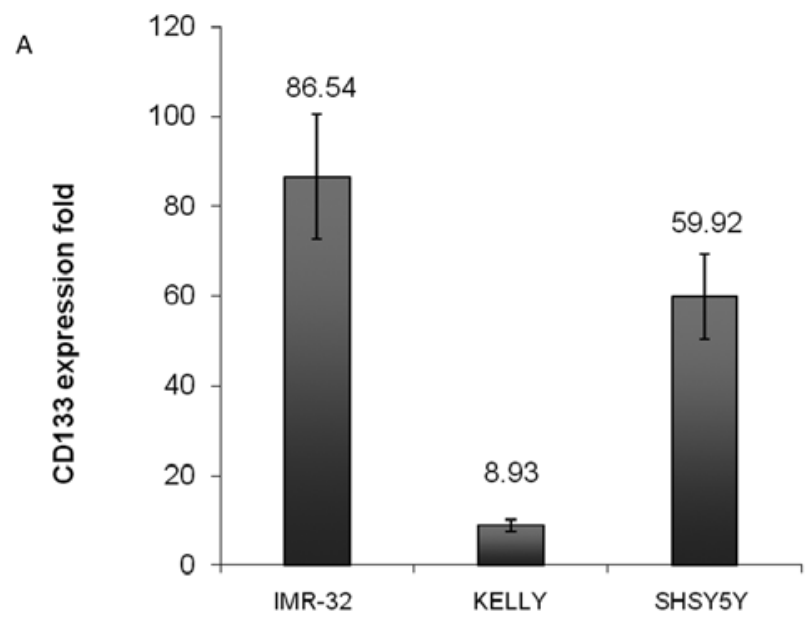

B

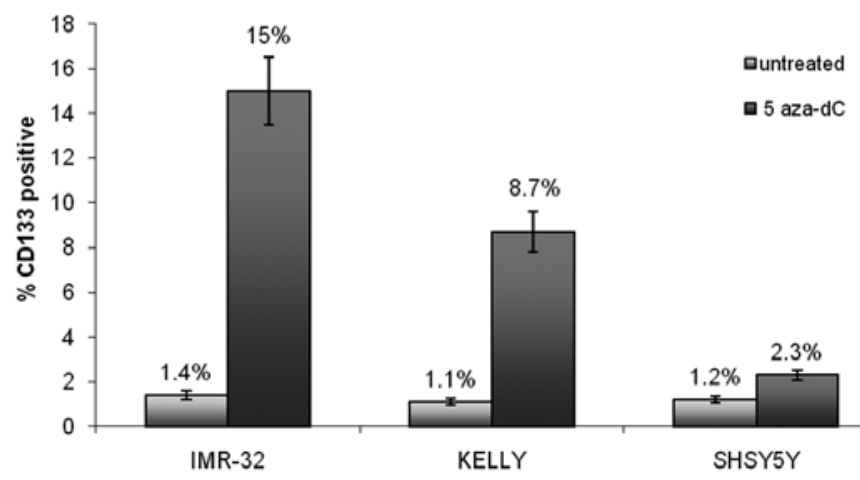

Figure 2. Real-time PCR and flow cytometry analysis of CD133 expression levels after 5-Aza-dC treatment. (A) Data represent the fold change on RNA level of treated cells regarding untreated cells normalized for HPRT housekeeping gene. (B) Percentage of CD133 positive cells in treated and untreated cells.

SKNDZ, SKNSH, SKNBE(2) and MHHNB11. This group contains cells expressing very high percentage of CD133 (SIMA, SKNDZ) or moderate levels [SKNSH, SKNBE(2), MHHNB11]. The remaining cell lines analyzed [IMR-32,
SKNF1, KELLY, SHSYSY, and BE(2)C], displayed a halfmethylated promoter status, consistent with their low level of CD133 expression.

Re-expression of CD133 at the RNA level. We performed a demethylation assay using the demethylating agent, 5-aza-dC. After treatment, we studied the expression change on RNA level of the 5 half-methylated cell lines by real-time PCR. We found an increase on CD133 RNA level in all halfmethylated cell lines. The fold change on RNA levels achieved was diverse, depending on the cell line (Fig. 2A): $86.54 \%$ (IMR-32), 8.93\% (KELLY), 59.92\% (SHSY5Y), 10\% (SKNF1), and $23.53 \%$ [BE(2)C].

Re-expression of CD133 at the protein level. For studying the effect of the demethylation assay on CD133 protein expression, the half-methylated cell lines were stained for CD133 marker and flow cytometry was performed. We found a fold increase in the surface protein expression ranging from 2 to $11 \%$ on all the half methylated cell lines (Fig. 2B and 3). BE(2)C and SKNF1 did not show an important increase on protein expression.

\section{Discussion}

CD133 has been identified as a powerful marker for cancer stem cells in several types of brain tumors such as medulloblastomas and glioblastomas (15). Cancer stem cells are significantly enriched in $\mathrm{CD} 133^{+}$subpopulations derived from all types of solid tumors (24). We found that most of the neuroblastoma cell lines expressed the CD133 marker by RT-PCR and flow cytometry. The analysis of CD133 at protein level revealed the existence of different patterns of expression in neuroblastoma cell lines as we found populations with very high content of $\mathrm{CD} 133^{+}$cells and others with moderate to low CD133 expression.

We decided to investigate whether epigenetic changes, such as methylation of $\mathrm{CpG}$ islands from the $\mathrm{CD} 133$ promoter, modified the expression of the gene in neuroblastoma cell lines containing $\mathrm{CD} 133^{+/-}$populations. Interestingly, we found that CD133 was half-methylated in 50\% of the neuroblastoma cell lines, and demethylation treatment with 5-Aza$\mathrm{dC}$ increased the CD133 expression at RNA and protein level 


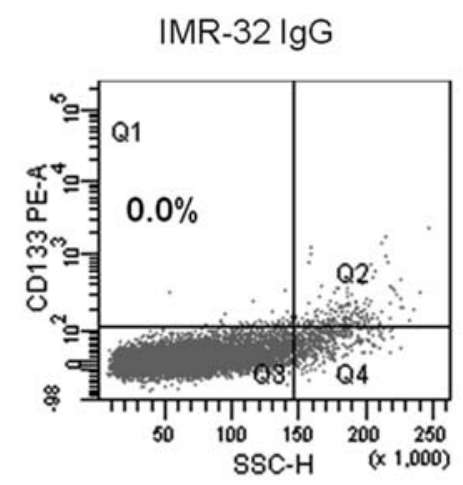

Kelly IgG

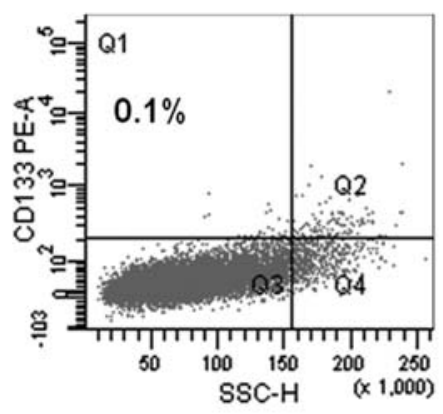

IMR-32 untreated

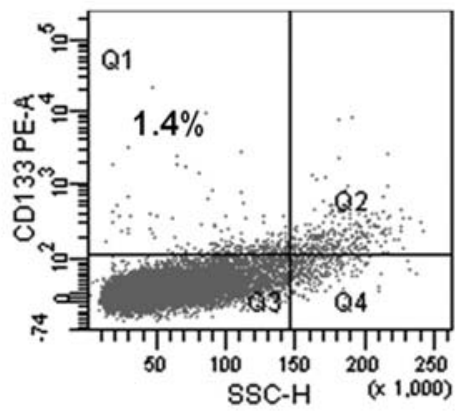

Kelly untreated

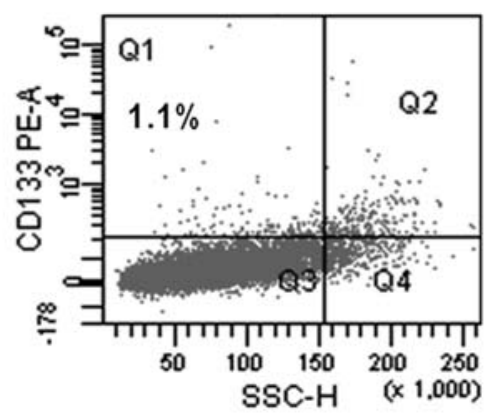

IMR-32 5-aza-dC

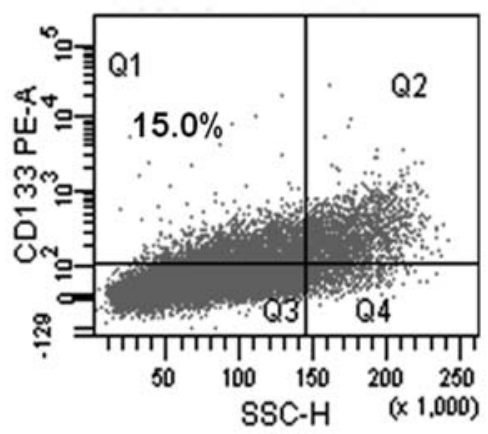

Kelly 5-aza-dC

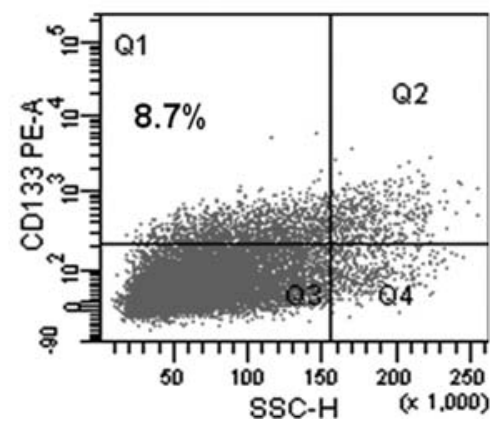

Figure 3. Flow cytometry analysis of CD133 expression after 5-Aza-dC demethylation assay. Increase of CD133 expressing cells in neuroblatoma cell lines after 5-Aza-dC demethylation treatment. Following 96 h, treated and untreated cells were stained for CD133-PE (mouse IgG was used as isotype control) and flow cytometry analysis was performed. The fluorescence of CD133 is depicted on the y axis, and the percentage of CD133+ cells (relative to the corresponding isotype control) is shown on the left upper corner of each plot.

in most of the half-methylated cell lines. Yi et al (21) found CD133 promoter methylation in glioblastomas and colorectal tumors, and interestingly, the abnormal methylation status was not found in normal brain or colon tissue, where CD133 is normally down-regulated during lineage commitment and cell differentiation, showing that a cancer-specific epigenetic change can be responsible for the regulation of CD133 expression. We also expanded our analysis of methylation status to other stem cell markers, such as NES, CD44, VIM and NCAM1 but we found that the promoter regions analyzed were unmethylated.

With regard to NES protein analysis, we found high levels of $\mathrm{NES}^{+}$cells in most of the neuroblastoma cell lines, but the percentage of $\mathrm{CD}_{133^{+}}$and $\mathrm{NES}^{+}$cells was not equivalent. A possible explanation is that NES expression has been linked to MYCN amplification in neuroblastoma cell lines (25).

We found that all neuroblastoma cell lines expressed high levels of MELK1, a gene that has been found to be highly expressed in NSC and malignant brain tumors such as glioblastoma. MELK1 knockdown by siRNA resulted in reducing the survival and producing the depletion of stem cells isolated from GB in vitro (26). The implication of this gene in neuroblastoma biology has not been described, but there is increasing evidence that it is required for NSC selfrenewal (27).

With regard to the differentiation markers analyzed, all neuroblastoma cell lines expressed the neuronal markers NCAM1 and TUBB3, but none of them showed expression of glial marker GFAP, which is in agreement with the neuroblastoma phenotype.

Among the other interesting markers analyzed, we must highlight the expression of SOX2, BMI1 and MSI1. BMI1 is required for the self-renewal capacity of several types of normal and cancer stem cells, including neural crest stem cells from the peripheral nervous system $(28,29)$ and has been previously shown to be important for neuroblastoma tumorigenesis (30). The transcription factor SOX2 is an essential gene due to its role in sustaining growth and selfrenewal of several stem cell types, both embryonic and adult $(31,32)$. In addition, it has been found to be expressed in a variable percentage of cells in several malignant tissues $(33,34)$. We found that SOX2, not previously studied in neuroblastoma, was expressed in most of the neuroblastoma cell lines analyzed.

We found that all our cell lines expressed different levels of MSI-1; interestingly, the highest percentage of expression was identified on CD133 high expressing cell lines, SIMA and SKNDZ. MSI1 is expressed predominantly in proliferating multipotent neural precursor cells, but not in newly generated postmitotic neurons (35). Nakano et al (36) examined MSI1 expression in human medulloblatomas and ependymomas, suggesting that MSI1 could be a useful marker for characterizing tumor heterogeneity and for examining the analogy between normal NSCs and MSI1+ cells in pediatric brain tumors.

Walton et al (8) performed an analysis of cellular heterogeneity in neuroblastoma cell lines. They found a population 
A
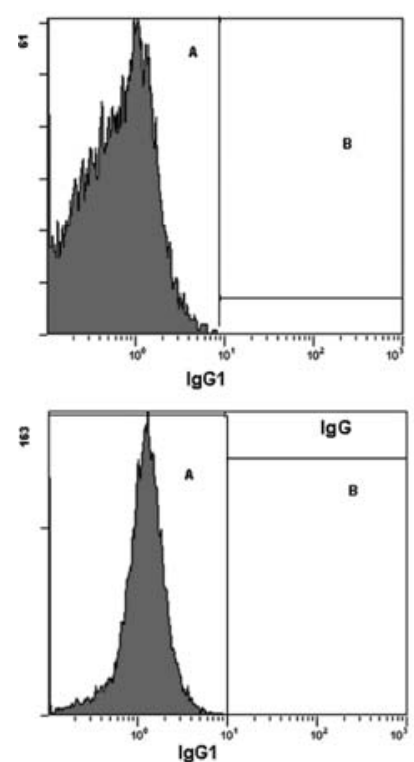

C
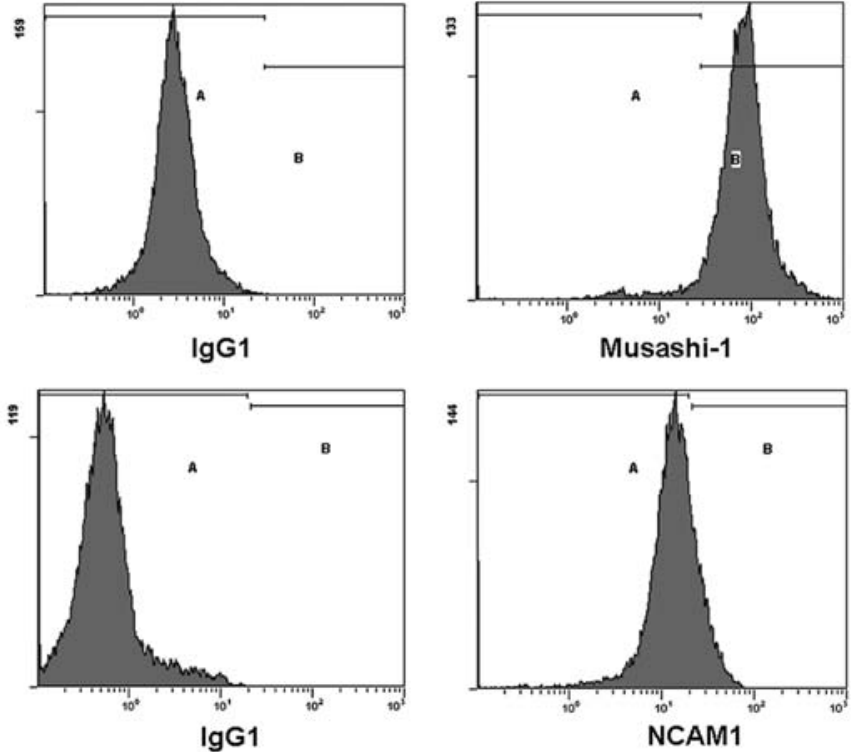

Figure 4. Analysis of CD133, Nestin (A) B-Tubulin III, Fas (B) Musashi-1 and NCAM1 (C) expression by flow cytometry in the neuroblastoma cell line SIMA.

called I-type cells (intermediate). These cells expressed CD133, and showed increased tumorigenicity in soft agar and in athymic mice. Other studies have demonstrated the presence of a side population in $65 \%$ of neuroblastoma tumors (37) together with the expression of several nonneuronal, neuroblastic, and stem cell markers in different isolated populations of neuroblastoma cell lines (23).

Brain tumor initiating cells often feature the $\mathrm{CD}_{133^{+}} /$ musashi- $1^{+} /$nestin $^{+}$or similar phenotypes. Our flow cytometry analysis corroborates these findings as we observed this kind of subpopulation in neuroblastoma cell lines. This group of 'stemness genes' can confer a phenotype responsible for
B
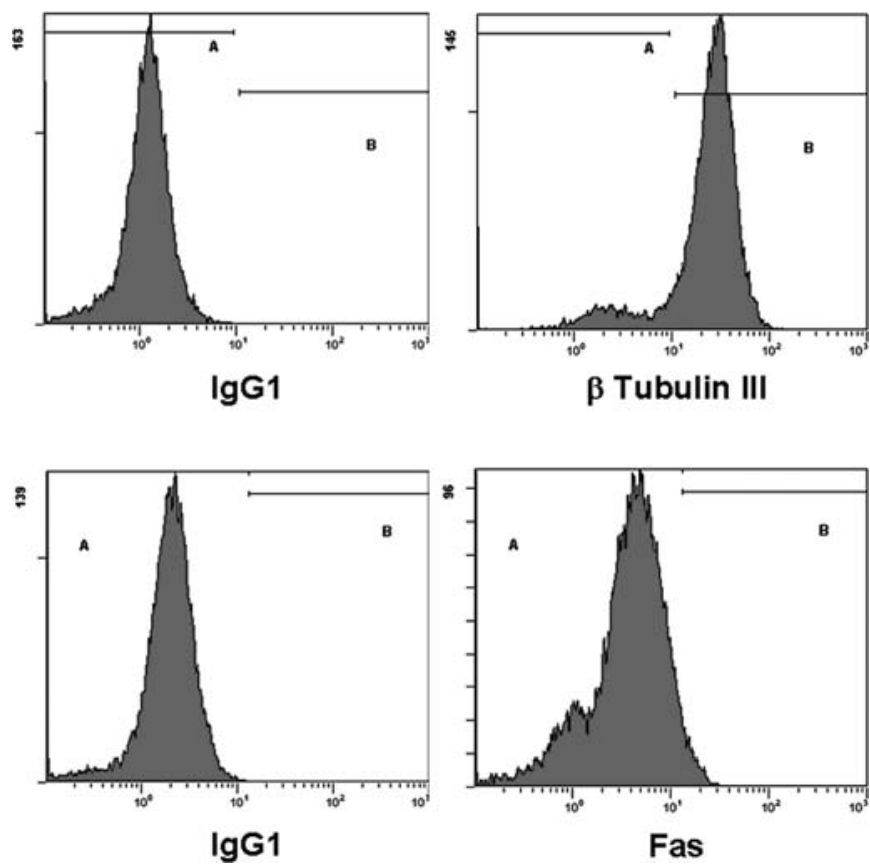

tumor metastasis, escape from anticancer therapies, and ultimately, disease relapse. There is increasing evidence of the presence of tumor stem cells in neuroblastoma cell lines and tumors. Innovative strategies for targeting these cells are vital for the improvement of patient outcome and are expected to increase treatment success and prevent relapse. Further characterization of neuroblastoma stem cells might be critical for the improvement of anti-cancer therapeutics to target cancer stem cell populations in human malignancies.

\section{Acknowledgements}

We would like to thank Izaskun Gabari from CIMA, University of Navarra, for performing flow cytometry analyses of CD133; and Laura Stokes for proofreading the manuscript. P. Schiapparelli, M. Enguita-Germán and J. Balbuena would like to thank the Asociación de Amigos de la Universidad de Navarra and the Departamento de Educación del Gobierno de Navarra for the fellowships received. J.S. Castresana thanks the Asociación Española de Pediatría for the VIII Premio Nutribén de Investigación Pediátrica, Madrid. This study was supported in part by grants from the Departmento de Salud del Gobierno de Navarra (9/07), Caja Navarra (08/13912), and Fundación Universitaria de Navarra, Pamplona; and Fondo de Investigación Sanitaria (PI081849), Madrid.

\section{References}

1. Grimmer MR and Weiss WA: Childhood tumors of the nervous system as disorders of normal development. Curr Opin Pediatr 18: 634-638, 2006.

2. Polyak K and Hahn WC: Roots and stems: stem cells in cancer. Nat Med 12: 296-300, 2006.

3. Hemmati HD, Nakano I, Lazareff JA, et al: Cancerous stem cells can arise from pediatric brain tumors. Proc Natl Acad Sci USA 100: 15178-15183, 2003.

4. Johnsen JI, Kogner P, Albihn A and Henriksson MA: Embryonal neural tumours and cell death. Apoptosis 14: 424-438, 2009. 
5. Lasky JL III, Choe M and Nakano I: Cancer stem cells in pediatric brain tumors. Curr Stem Cell Res Ther 4: 298-305, 2009.

6. Mahller YY, Williams JP, Baird WH, et al: Neuroblastoma cell lines contain pluripotent tumor initiating cells that are susceptible to a targeted oncolytic virus. PLoS One 4: e4235, 2009.

7. Maris JM, Hogarty MD, Bagatell R and Cohn SL: Neuroblastoma. Lancet 369: 2106-2120, 2007.

8. Walton JD, Kattan DR, Thomas SK, et al: Characteristics of stem cells from human neuroblastoma cell lines and in tumors. Neoplasia 6: 838-845, 2004

9. Corbeil D, Fargeas CA and Huttner WB: Rat prominin, like its mouse and human orthologues, is a pentaspan membrane glycoprotein. Biochem Biophys Res Commun 285: 939-944, 2001.

10. Miraglia S, Godfrey W, Yin AH, et al: A novel fivetransmembrane hematopoietic stem cell antigen: isolation, characterization, and molecular cloning. Blood 90: 5013-5021, 1997.

11. Yin AH, Miraglia S, Zanjani ED, et al: AC133, a novel marker for human hematopoietic stem and progenitor cells. Blood 90: 5002-5012, 1997.

12. Collins AT, Berry PA, Hyde C, Stower MJ and Maitland NJ: Prospective identification of tumorigenic prostate cancer stem cells. Cancer Res 65: 10946-10951, 2005.

13. Ogden AT, Waziri AE, Lochhead RA, et al: Identification of $\mathrm{A} 2 \mathrm{~B} 5^{+} \mathrm{CD} 133^{-}$tumor-initiating cells in adult human gliomas. Neurosurgery 62: 505-514, 2008.

14. Ponnusamy MP and Batra SK: Ovarian cancer: emerging concept on cancer stem cells. J Ovarian Res 1: 4, 2008.

15. Singh SK, Hawkins C, Clarke ID, et al: Identification of human brain tumour initiating cells. Nature 432: 396-401, 2004.

16. Shmelkov SV, Jun L, St Clair R, et al: Alternative promoters regulate transcription of the gene that encodes stem cell surface protein AC133. Blood 103: 2055-2061, 2004.

17. Feinberg AP and Tycko B: The history of cancer epigenetics. Nat Rev Cancer 4: 143-153, 2004.

18. Herman JG and Baylin SB: Gene silencing in cancer in association with promoter hypermethylation. N Engl J Med 349 2042-2054, 2003.

19. Baba T, Convery PA, Matsumura N, et al: Epigenetic regulation of CD133 and tumorigenicity of CD133+ ovarian cancer cells. Oncogene 28: 209-218, 2009.

20. Tabu K, Sasai K, Kimura T, et al: Promoter hypomethylation regulates CD133 expression in human gliomas. Cell Res 18 1037-1046, 2008.

21. Yi JM, Tsai HC, Glockner SC, et al: Abnormal DNA methylation of CD133 in colorectal and glioblastoma tumors. Cancer Res 68: 8094-8103, 2008
22. Ootsuka S, Asami S, Sasaki T, et al: Analyses of novel prognostic factors in neuroblastoma patients. Biol Pharm Bull 30: 2294-2299, 2007.

23. Ross RA and Spengler BA: Human neuroblastoma stem cells. Semin Cancer Biol 17: 241-247, 2007.

24. Mizrak D, Brittan M and Alison MR: CD133: molecule of the moment. J Pathol 214: 3-9, 2008.

25. Thomas SK, Messam CA, Spengler BA, Biedler JL and Ross RA: Nestin is a potential mediator of malignancy in human neuroblastoma cells. J Biol Chem 279: 27994-27999, 2004.

26. Nakano I, Masterman-Smith M, Saigusa K, et al: Maternal embryonic leucine zipper kinase is a key regulator of the proliferation of malignant brain tumors, including brain tumor stem cells. J Neurosci Res 86: 48-60, 2008.

27. Nakano I, Paucar AA, Bajpai R, et al: Maternal embryonic leucine zipper kinase (MELK) regulates multipotent neural progenitor proliferation. J Cell Biol 170: 413-427, 2005.

28. Iwama A, Oguro H, Negishi M, et al: Enhanced self-renewal of hematopoietic stem cells mediated by the polycomb gene product BMI-1. Immunity 21: 843-851, 2004.

29. Molofsky AV, Pardal R, Iwashita T, Park IK, Clarke MF and Morrison SJ: BMI-1 dependence distinguishes neural stem cell self-renewal from progenitor proliferation. Nature 425: 962-967, 2003.

30. Cui $\mathrm{H}, \mathrm{Hu} \mathrm{B}, \mathrm{Li} \mathrm{T}$, et al: BMI-1 is essential for the tumorigenicity of neuroblastoma cells. Am J Pathol 170: 1370-1378, 2007.

31. Lee TI, Jenner RG, Boyer LA, et al: Control of developmental regulators by Polycomb in human embryonic stem cells. Cell 125: 301-313, 2006.

32. Masui S, Nakatake Y, Toyooka Y, et al: Pluripotency governed by Sox 2 via regulation of Oct3/4 expression in mouse embryonic stem cells. Nat Cell Biol 9: 625-635, 2007.

33. Rodriguez-Pinilla SM, Sarrio D, Moreno-Bueno G, et al: Sox2: a possible driver of the basal-like phenotype in sporadic breast cancer. Mod Pathol 20: 474-481, 2007.

34. Schmitz M, Temme A, Senner V, et al: Identification of SOX2 as a novel glioma-associated antigen and potential target for T cell-based immunotherapy. Br J Cancer 96: 1293-1301, 2007.

35. Maslov AY, Barone TA, Plunkett RJ and Pruitt SC: Neural stem cell detection, characterization, and age-related changes in the subventricular zone of mice. J Neurosci 24: 1726-1733, 2004.

36. Nakano A, Kanemura Y, Mori K, et al: Expression of the Neural RNA-binding protein Musashil in pediatric brain tumors. Pediatr Neurosurg 43: 279-284, 2007.

37. Hirschmann-Jax C, Foster AE, Wulf GG, et al: A distinct 'side population' of cells with high drug efflux capacity in human tumor cells. Proc Natl Acad Sci USA 101: 14228-14233, 2004. 